\title{
Social Mix Policies in the French Eco-Districts: Discourses, Policies and Social Impacts
}

\author{
Machline E. ${ }^{1}$, Pearlmutter D. ${ }^{2} \&$ Schwartz M. ${ }^{2}$ \\ ${ }^{1}$ Urban Development and Mobility department, Luxembourg Institute for Socio-economic Research, Esch Sur \\ Alzette, Luxembourg \\ ${ }^{2}$ Blaustein Institutes for Desert research, Ben Gurion University of the Negev, Be'er Sheva, Israel \\ Correspondance: Elise Machline, Urban Development and Mobility department, Luxembourg Institute for \\ Socio-economic Research, Esch Sur Alzette, Luxembourg. E-mail: elise.machline@ liser.lu
}

Received: May 6, 2020

Accepted: June 4, 2020

Online Published: June 10, 2020

doi:10.5539/eer.v10n1p36

URL: https://doi.org/10.5539/eer.v10n1p36

\begin{abstract}
In the 1960s, France built large high-rise developments to house poor and immigrant populations. This policy led to the rise of crime and violent unrest in those developments. Responding to that failure, France has tried, especially since the eighties, to promote a social mix policy in its new housing developments. In the first decade of the twenty first century, France elaborated an eco-district (eco-quartier) program whose guidelines emphasize the goals of this social mix policy together with affordability in public social housing. In light of these developments, this paper focuses on the socio-economic aspects of French eco-districts, especially with respect to low-income populations. The eco-quartier housing distribution has shown that social mix goals are barely reached. In affluent cities, where property prices are high (such as Paris, its middle-class suburbs and some large cities), the municipalities build eco-quartiers in substandard neighborhoods, to attract middle class families. In average cities, some municipalities have implemented more social housing than planned, to provide developers with access to State subsidies and loans - but can still privilege the middle-class in the allocation of the resulting housing. In the poorest French towns, eco-quartiers can improve living conditions for local residents but do not effectively promote social mixing.
\end{abstract}

Keywords: climate changes mitigation, Eco-districts, social housing policy, 'Green' building, gentrification

\section{Introduction}

Large housing projects were built in France for the working class from 1956 on (mostly in the 1960s and 70s), to deal with the serious housing crisis that the country was facing after the Second World War (Blanc, 2004). The construction of three million dwelling units in large high rises within ten years was expected to solve the crisis. In the 1960s, these French suburban social housing estates accommodated their first residents. In the seventies the estates turned into vertical slums. Since the late 1970s, French middle-class families have been deserting them, usually to move into a single-family house in a more distant suburb. Those who cannot afford to move out are mainly second-generation black and Arab immigrants from French ex-colonies. The vertical slums are characterized by high rates of poverty and unemployment (Lapeyronnie, 2008, p. 416).

Whereas discussions about ethnic and class segregation have a long history in America, France has tried to overlook or deny its own segregation practices (Massey, 1981), as they expose its failure to live up to the republican ideals of Equality and Fraternity. Severe riots in the fall of 2005 dramatized ethnic segregation, stunning public opinion.

In response to the dire effects of the growing spatial concentration of poor and minority ethnic groups in the 1980 s, social mix came to be viewed as a means to regenerate social housing estates in Western Europe (Atkinson, 2008). In France the national urban renewal program (Programme National de Rénovation Urbaine) launched in 2003, stated the aim of "encouraging social mix and sustainable development" (Note 1). As in other countries, the tearing down of French social housing in deprived neighborhoods, aims to disperse poor people while the new, more expensive private housing developments replacing it are meant to bring in middle-class households (Lévy-Vroelant, 2007). This policy assumes that more social diversity in poor neighborhoods will improve their economic viability, as well as their reputation and the quality of life they offer. Furthermore, the 
policy assumes that such diversity generates social interaction and opportunities benefitting the poorest populations (Tunstall \& Fenton, 2006). Researchers have shown that improving social cohesion through social mix is perceived as a means of strengthening social control, while reducing deviant behavior and personal insecurity (Kearns \& Mason, 2007). The implementation of a social mix policy assumes that the middle-class will play an integrating role for the working classes and that its presence in these neighborhoods will generate "social capital" (Flint \& Kearns, 2006). Social mix is to be ensured through housing diversity, in terms of price, dwelling size, typology (individual vs. collective), social/private housing or modality of access (purchase or rental).

Alongside these social challenges, there are growing environmental concerns, particularly regarding climate change, also connected to housing construction. About 70 percent of all greenhouse gas (GHG) emissions originate in urban areas (Grimm et al., 2008; UN Habitat, 2011). This challenges the building industry to become more environmentally responsible and resource-efficient (Sidler, 2007), an important challenge given that the residential sector represents a large source of potential energy savings (IPCC, 2007; Mckinsey, 2009). "Green building" refers to "the use of environmentally preferable practices and materials in the design, location, construction, and operation of buildings. It applies to the renovation and retrofitting of existing buildings, as well as to the construction of new ones, residential or commercial, public or private" (Commission for Environmental Cooperation, 2008).

In addition to building's design and construction (which directly affect the use of energy, water, and materials), green building takes into account other environmental issues, ranging from ongoing building operation to urban planning aimed at reducing the reliance on private cars. The introduction of neighborhood-level green building standards, has further extended the scope of sustainability topics, as well as the range of stakeholders, including municipal authorities, whose role is likely to expand in the future. While national policies strongly affect local energy consumption patterns, as well as the generation and disposal of pollutants, city planning and policies can help reduce GHG emissions, promoting sustainable development (Bulkeley et al., 2011).

In 2008, the European Commission launched the Covenant of Mayors (Note 2). Signatories agreed to meet and exceed the EU target of a 20 percent reduction in GHG emissions (from 1990 levels) by 2020. With more than 5000 signatories, the Covenant is the leading movement in Europe supporting local and regional authorities in achieving this goal. Some European cities started focusing on climate change well before signing the Covenant, making significant inroads in GHG reduction: the achievements of Stockholm, Malmö, Freiburg, Copenhagen, and others have been widely extolled (Note 3). One practice these cities have in common is the establishment of eco-districts - neighborhood scale developments addressing climate mitigation, energy savings, and the management of waste, transport and water resources. The establishment of such eco-districts may raise sustainable development standards throughout a city. There is a growing literature on eco-districts, but little systematic analysis of their effectiveness in attracting affluent populations or enhancing affordability. In 2008, the French Ministry of Ecology, Sustainable Development and Energy launched a national program of Eco-Districts (Éco-quartiers) as part of the ministerial plan "Sustainable City" (Plan Ville Durable). According to the eco-quartier framework requirements (2009), there should be a socio-economic, generational and cultural population mix within the neighborhood - in sharp contrast to the large post-war housing projects built exclusively for the poor (Blanc, 2004). However, the 186 certified eco-quartiers (2017) represent only 55,000 housing units (French Ministry of Housing, 2018) - less than 2\% of the three million public housing units built in the 1950s and 60s.

Social mix in the eco-quartiers is meant to be ensured through housing diversity, i.e. in price, dwelling size, typology (individual vs. collective), social/private housing or modality of access (purchase or rental). The actualization of such a housing mix requires, however, exceptional funding methods to control home prices. Indeed, the construction costs of high ecological performance apartments have been estimated to be10 to $20 \%$ higher than those of regular apartments (Guinand, 2007) (Note 4). Souami confirms that such funding is often necessary to make these neighborhoods affordable to all $(2009$, p. 80). According to his analysis, for the winners of the Eco-quartier call for proposals in 2009, public subsidies complementing ordinary funding represent from 10 to $95 \%$ of the gains ( $22 \%$ on average). These benefits are funded by regional and general councils (for example, through specific EcoFaur ${ }^{2}$ schemes for the Brittany region), Land companies, ADEME, or the European Commission (calls for projects make the funding possible for exemplary projects, as was the case for the De Bonne eco-quartier in Grenoble, with Concerto subsidies (Note 5)). The European Commission allocated 3.9 million euros to the Concerto program for energy saving measures.

Projects for "sustainable districts" can also help implement some requirements, through special subsidies. For example, the call for projects of New Urban Neighborhoods promises subsidies of more than 3000 euros per 
dwelling built.

In sum, the three types of calls for 'sustainable districts' support project promotion and sometimes help carry out studies. For example, the winners of the ANRU (Urban Renewal and Sustainable Town Planning) calls were awarded $€ 100,000$ each by the Caisse des Dépôts et Consignations for engineering studies. The winners of the New Urban Neighborhoods received between 1300 and $4900 €$ per apartment built before 2013, which they can use to carry out studies or complete operation funding.

The additional costs linked to 'green' building are relatively unchallenged, in the name of the "superior cause" (Souami, 2009, p. 82) of sustainable development.

This paper will illustrate how different municipalities have apportioned housing in their eco-quartiers to attract the middle class, under the guise of social mix. Our research aims to understand whether French policy tools do actually promote social diversity and affordability in eco-districts in various locations (Paris, vs. peripheries like Bretigny Sur Orge and relatively distant locations, such as Reims).

\section{The French Eco-District Scheme}

While the French 'green' building label (BBC) only sets a standard for energy consumption, the eco-quartier scheme involves social issues as well. According to program requirements, the local authority must ascertain "that housing location and prices are appropriate for household income" Certification file (2015), Second dimension (Living environment and use)-Commitment 7 (Social Diversity) (Note 6) (see the Eco-quartier guidelines in annex).

The initiators of the eco-quartiers emphasized that the inclusion of planning measures promoting social mix, is a decisive criterion in assessing project applications. According to the Head of the Sustainable Planning Unit of the Ministry of Housing, Equality of Territories and Rurality (2015):

"The social aspect is the French peculiarity; a project without social mix, not taking social issues into account, cannot be an eco-quartier. In any case, it will not be an eco-quartier as perceived by the Ministry [...] and it is incompatible with how we consider sustainable development in France! [...] Our aim is to promote the idea of social mix. We want to give all people the opportunity to live in an eco-quartier. The aim is not to sell the apartments at a higher price". De Chastenet et al. (2016) argue that "we are far from the edge cities, which are fully funded by private groups, aiming to produce luxury neighborhoods for urban gentrification".

Jean-Louis Borloo, Minister of Ecology, Energy, Sustainable Development and City and Country Planning in 2009, insisted that social issues be taken into account in the design of eco-quartiers: "Eco-quartiers and eco-cities also have a social and economic role to play [...]: they must make a strong contribution to developing social cohesion and reducing territorial inequalities." (Note 7).

In general, the eco-quartier call for proposals seeks above all to avoid social segregation. The social dimension remains restricted to the search for population diversity, both "to reduce socio-spatial segregation" within the neighborhood and "to improve social cohesion" by "strengthening social ties" (MoESDTH (Note 8), 2009).

The definition given by the Regional Agency for Environment and Energy of Ile de France (ARENE), explains that social effects are a central objective: "Sustainable neighborhood development takes into account all effects, at the environmental level as well as at the economic and social levels, during both the preparation of the project and its operational phase" (Note 9). This distinguishes the eco-quartiers from 'sustainable' districts in Europe, criticized for having become "ghettos for bobos (Bohemian Bourgeois (Note 10))" (Emelianoff, 2011, p. 3), and claiming a "French approach" to generating sustainable neighborhoods: without gentrification. "The eco-quartier is not the refuge of a few, like the American condominiums. It must be open (accessible to all). The eco-quartier therefore aims at several kinds of mixing: social (by socio-professional category and activity), generational (by age), and by family structure (nature and size of the household)."(Charlot-Valdieu \& Outrequin, 2009, p. 60). For example, the "eco-quartier" charter of Lille (a city at the northern tip of France, in French Flanders) emphasizes social aspects, most of all social mix: "One often hears that an eco-quartier is reserved for the 'bobos'. On the contrary, a fundamental objective of the eco-quartier is promoting social mix, by offering a variety of housing types capable of meeting the needs of all: large and small dwellings, housing for the elderly and young people as well as families, and private dwellings, together with social housing. In addition, an eco-quartier should be a well-connected neighborhood, close to everything, with more nature and less pollution ... in a word: a more pleasant neighborhood! Who wants to live in a neighborhood like this? Everybody!" (Note 11).

This consideration of social aspects was, however, seen as complementary to environmental objectives: the main focus was on the technical 'green' aspects, to ensure the projects' ecological performance. The awarding of credits in the Lille eco-quartier call for projects indicates a priority for balance: the thematic ranking of projects 
(of Eco-quartier 2009) includes categories related to water, urban biodiversity/nature in the city, waste, energy savings, mobility, and 'green' building. The only category pertaining to the projects' social dimension is "density and urban form". The initial approach developed during the first Eco-quartier call, emphasizes the need to fight "social risks" in these neighborhoods, especially segregation. Thus, while the main thrust was to promote projects whose approach was 'green' in environmental terms, the inclusion of social responses was to prevent negative side-effects, such as socio-spatial segregation.

French local authorities have complex set of regulations, each of which has some influence on the planning and implementation of Eco-quartiers, mainly thermal regulations and the law on Solidarity and Urban Renewal (SRU, 2000). This web of actors, and their interactions determine green building funding in Eco-quartiers.

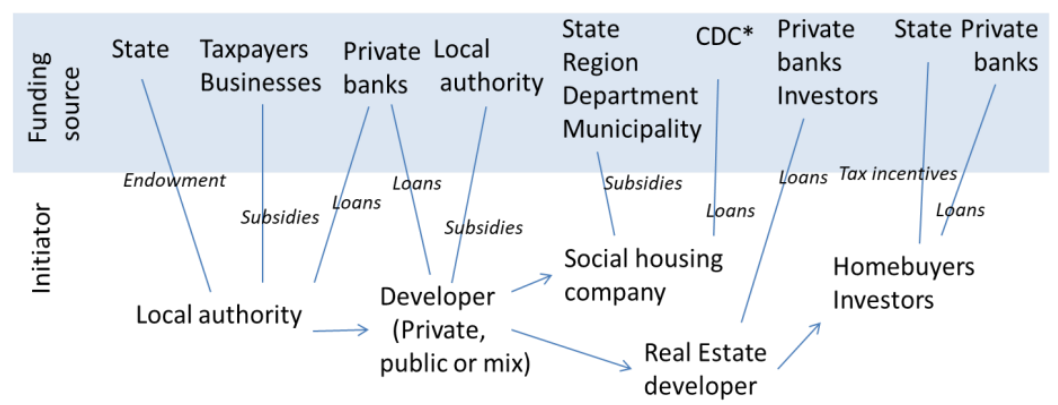

Figure 1. Stakeholders involved in Eco-quartier planning in France (Machline, 2017)

The Eco-quartiers have provided affordable housing thanks to subsidies at the European, State, regional, departmental and municipal levels, as well as loans from the CDC ("Caisse des Dépôts et Consignations -Deposits and Consignments Fund"), a public financial institution established in 1916, under the control of the Parliament. Caisse des Dépôts has supported 15 eco-quartier projects, to strengthen their coherence throughout their progress rather than simply labeling them. In 2008, the Caisse des Dépôts group also launched a research and development strategy on the sustainable city, together with its real estate subsidiaries. The method of the Caisse des Dépôts was to do follow-ups on eco-quartier projects, selected according to their ambition and to the pragmatism they display in the pursuit of sustainable development.

Other public funds (national or European) support the thermal refurbishment of social housing. For example, the European fund "Concerto" has assisted the Eco-quartiers of Grenoble and Reims. The State Agency for the Improvement of Housing (ANAH) allocates subsidies for the rehabilitation of buildings older than 15 years. The goal is helping privately owned buildings which are owner-occupied or rented as primary residences. The target group of owner-occupiers is limited to those whose economic resources are beyond a certain limit. Buildings and housing units eligible for subsidies are those with insufficiencies regarding safety, impacts on health, appliances and housing quality (ANAH, 2006; ADEME, 2006a).

An older subsidy program called PALULOS was launched in 1977 to address the lack of maintenance in rental social housing owned or managed by social entities. As with ANAH, eligible projects include improvements in safety and comfort, upgrades for compliance with regulations and housing norms, and energy savings (Note 12). Buildings must be at least 15 years old, but for energy conservation improvements they must hail back to July 1981 or earlier. The subsidies are attributed as a percentage of the renovation costs, up to a maximum amount, usually 13000 Euros per housing unit (Note 13).

The Ministry decided in 2014 to grant a 30,000 Euro subsidy to each local authority that obtained the Eco-quartier certification by implementing a monitoring and evaluation method. Thanks to this funding system, even poor municipalities can design and monitor an eco-quartier including 'green' and affordable housing.

\section{Methodology}

Case studies are appropriate when the researcher has little control over events and wants to find out how a phenomenon has happened, or why (Yin, 2009). The case study method is used in ethnography, surveys, quantitative modelling etc. (Yin, 2011), and values the use of multiple sources of evidence, to foster reliability and improve understanding. Case studies can be used to test theories, or deepen our understanding (de Vaus, 2001), as we have attempted to do in the present study. 
We have selected three eco-quartiers for intensive data collection:

- An eco-quartier in Paris (Claude Bernard Eco-quartier) that received the national label and where the apartment buildings are certified 'green' (BBC-effinergie certification)

- The "Clause Bois Badeau" Eco-quartier in Bretigny Sur Orge, that also includes BBC-effinergie housing.

- The "Pays de France" eco-quartier in Reims, where the housing also received the BBC-effinergie label.

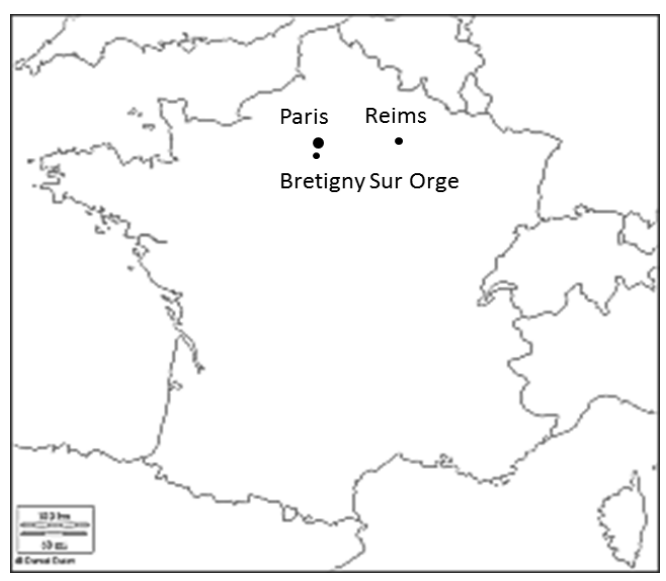

Figure 1. The three case studies in France

Map: Machline, 2017.

We selected three (though not geographically) representative case studies according to the municipality's socio-economics data as detailed in the following table (we did not include villages and the overseas cities (Note 14)).

Table 1. Selected socio-economic data

\begin{tabular}{|c|c|c|c|c|c|c|}
\hline Municipality & $\begin{array}{l}\text { Poverty } \\
\text { rate } 2015\end{array}$ & $\begin{array}{l}\text { Average income } \\
\text { of the poorest } \\
\left(1^{\text {st }} \text { dec. }\right) 2015\end{array}$ & $\begin{array}{l}\text { Average income } \\
\text { of the richest } \\
\left(9^{\text {th }} \mathrm{dec} .\right) 2015 \\
\end{array}$ & $\begin{array}{l}\text { Ratio of standard } \\
\text { of living (9th } \\
\text { dec./ } / 1^{\text {st }} \text { dec.) } 2015\end{array}$ & $\begin{array}{l}\text { Share of } \\
\text { income } \\
\text { taxes } 2015 \\
\end{array}$ & $\begin{array}{l}\text { Median standard } \\
\text { of living } \\
2015\end{array}$ \\
\hline Paris & 16.2 & 9864 & 63781 & 6.5 & -27.4 & 26431 \\
\hline Boulogne-Billancourt & 9.7 & 12528 & 67469 & 5.4 & -27.5 & 31268 \\
\hline Levallois-Perret & 9.1 & 12833 & 65018 & 5.1 & -26.8 & 30504 \\
\hline Nanterre & 21.2 & 9472 & 39218 & 4.1 & -17.5 & 19170 \\
\hline Brétigny-sur-Orge & 12.6 & 11541 & 36879 & 3.2 & -17.7 & 21875 \\
\hline Bordeaux & 17.2 & 9868 & 44568 & 4.5 & -20.9 & 21404 \\
\hline Tours & 19.9 & 9469 & 36447 & 3.8 & -17.4 & 19133 \\
\hline Angers & 19.9 & 9576 & 36538 & 3.8 & -16.6 & 19194 \\
\hline Mantes-la-Jolie & 32.5 & 8147 & 29218 & 3.6 & -14.7 & 15410 \\
\hline Reims & 22.8 & 9205 & 35312 & 3.8 & -17.3 & 18231 \\
\hline Lille & 25.7 & 8710 & 37099 & 4.3 & -17.9 & 18102 \\
\hline Lyon & 14.6 & 10720 & 44743 & 4.2 & -20.6 & 22501 \\
\hline Mulhouse & 33.2 & 8326 & 32167 & 3.9 & -15.9 & 15371 \\
\hline Grenoble & 19 & 9709 & 37843 & 3.9 & -17.6 & 20066 \\
\hline Saint-Brieuc & 19.8 & 9656 & 34198 & 3.5 & -16.4 & 18838 \\
\hline Ivry-sur-Seine & 27.9 & 7735 & 34427 & 4.5 & -16.7 & 17406 \\
\hline Montpellier & 26.5 & 8546 & 35687 & 4.2 & -17.6 & 17640 \\
\hline
\end{tabular}

Source: INSEE, 2018.

Then, we have been able to identify the following categories represented by our three case studies 
Table 2. The Socio-economic characteristics of the Eco-quartier municipalities

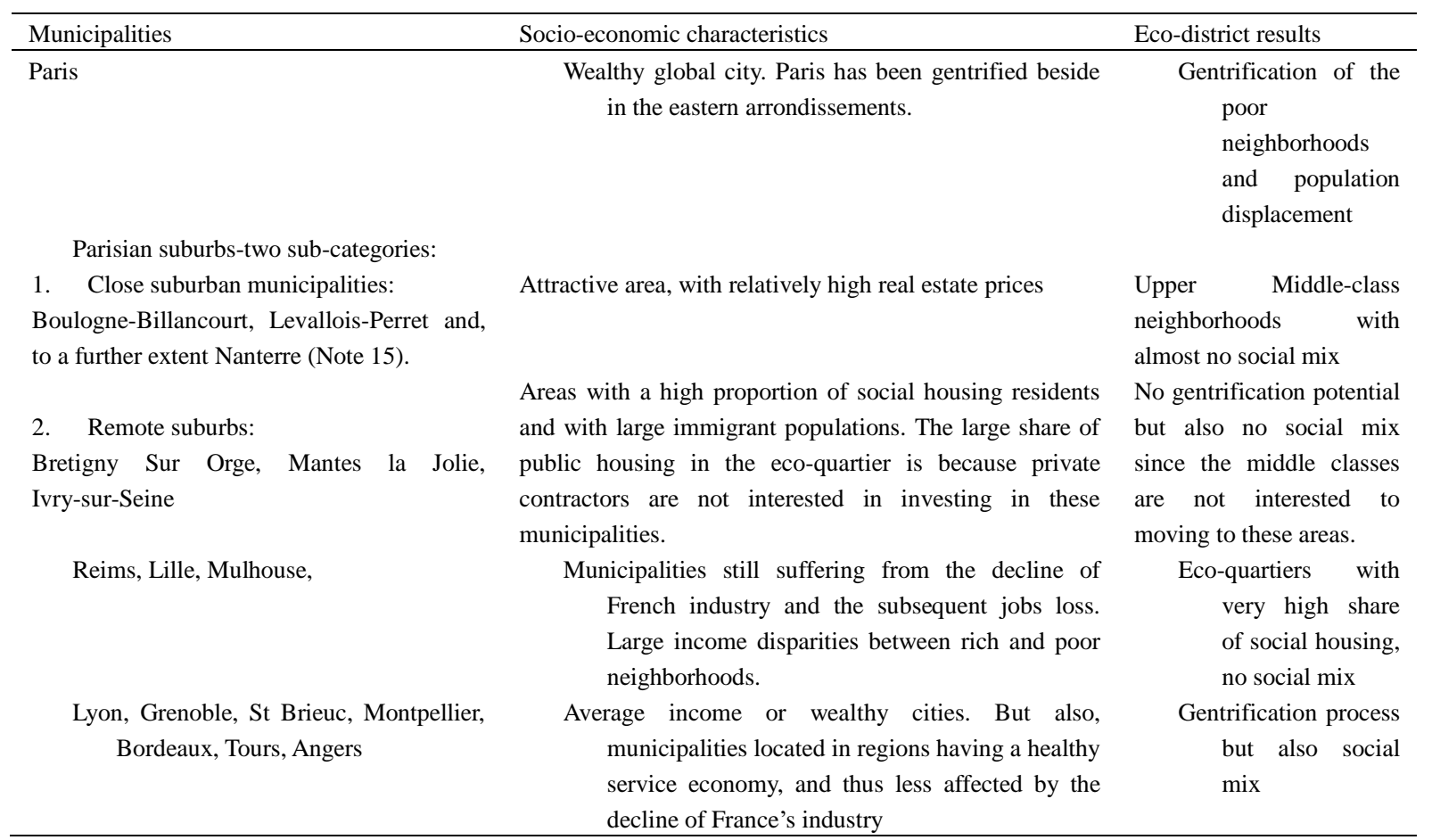

Source: Observatoire des inegalités, 2011.

France is one of the more affluent countries in the OECD, but exhibits significant poverty and meaningful inequalities of income, wealth, and life outcomes. The past several years of rising unemployment have worsened these circumstances. This variation often occurs across the lines of ethnicity and national origins; immigrant communities in France tend to have significantly higher levels of poverty, unemployment, and health disparities, often concentrated in specific suburbs of major cities. To be considered to be living in poverty an individual must survive on $€ 977$ per month, after taxes and including government subsidies. That sum is 60 percent of the national average income (Maurin, 2018).

Our three eco-quartier case studies are representative of three of the detailed categories of municipalities detailed above: (1): The Parisian metropolis with a high average income (though a few poor neighborhoods remain, mostly in eastern Paris, 18, 19, and 20 $0^{\text {th }}$ district); (2) Parisian remote suburbs like Bretigny Sur Orge with high share of low-income social housing; (3) Municipalities like Reims with high rates of poverty and large income disparities between poor and rich neighborhoods.

The logic of case study selection was to analyze how the green building concept was developed, considering the municipality's location (core-periphery), housing policy and socio-economic status. We considered the major city (Note 16) (Paris), one of its remote suburbs (Bretigny Sur Orge), and a low-income French eastern peripheral city (Reims). The aim was to find out whether the location and the socio-economic status of the municipality affected the input of 'green' and affordable housing.

Fieldwork included interviews and participant observation in key professional events, as well as analysis of documents from a variety of sources (policy-making bodies, NGOs, interest groups, experts, the media).

The analysis aimed to (1) identify the key policy tools designed to promote green affordable housing; (2) gather evaluations of their application through analysis of documents, including policy reports, central and local government action plans, professional NGO reports, statements of opinion, newspaper articles, protocols of municipality meetings, and academic research reports.

Interviews were conducted with key figures in green building, selected by the positions they hold in the field (Scott, 1991). During initial fieldwork in France, in April 2015, semi-structured interviews were conducted among stakeholder representatives of organizations involved in green affordable housing (i.e. the French Ministry of Housing, the Equality of Territories and Rurality (Eco-district) framework, the French Environment Energy Management Agency (ADEME), social housing companies, the Housing Authority of the Paris Municipality, Urbanism Department of Paris Municipality, design offices, and environmental consultants. 
During our second fieldwork period in France, in April 2016, interviews were conducted with stakeholder representatives in the local authorities corresponding to the three case studies (in Paris, Bretigny sur Orge and Reims), and a second interview was conducted with the head of the Eco-quartier program at the Ministry of Housing, aiming to understand the evolution of the label's requirements. An internet survey was carried out in 2016 among municipalities including at least one eco-quartier. We aimed to collect data on housing distribution (private apartments/social housing for low-income/middle-class/upper middle-class) in all certified French eco-districts.

\section{Results}

\section{The Major City: Paris}

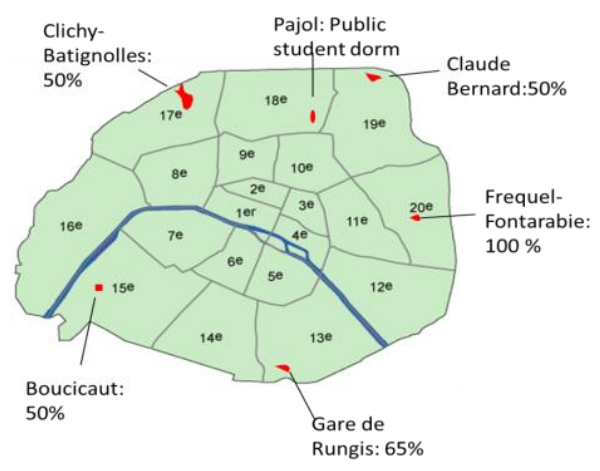

Figure 2. The eco-quartiers of Paris

Source: Machline et al., 2016.

The map in Figure 2 represents eco-quartier distribution among the twenty administrative districts (arrondissements) of Paris: Boucicaut (15th), Gare de Rungis (13th), Clichy-Batignolles (17th), Claude Bernard (19th), Frequel-Fontarabie (20th), and Pajol (18th). So far, they include only $0.6 \%$ of the Paris population (Paris municipality, 2015) and half of their housing units are social housing. Thus, in Claude Bernard eco-quartier, half of the dwellings are public housing, $25 \%$ private rental housing (controlled rent) and $25 \%$ private apartments of various sizes and kind (such as a home for elderly, student dormitory...) to ensure social mix. It was mentioned in the eco-quartier guidelines that public housing for the upper middle-class should compensate for the high share of low-income households in the neighborhood (see the socio-economic classification in France, Annex Table 2). In 2009, the private apartments were sold for $€ 6,250 /$ sq.m. (according to the developer's representative), well above the $19^{\text {th }}$ arrondissement average of $€ 4,900 /$ sq.m., but slightly below the new apartment average price at the time ( $€ 6,500$ /sq.m.). According to the neighborhood developer representative (personal communication, 2016), the promoter had to decrease apartment prices to sell them, because "no one would have bought an apartment in that neighborhood - next to the highway, without public transportation, and with so many prostitutes and drug dealers".

The eco-quartiers: affordable housing or hidden 'green gentrification'? 


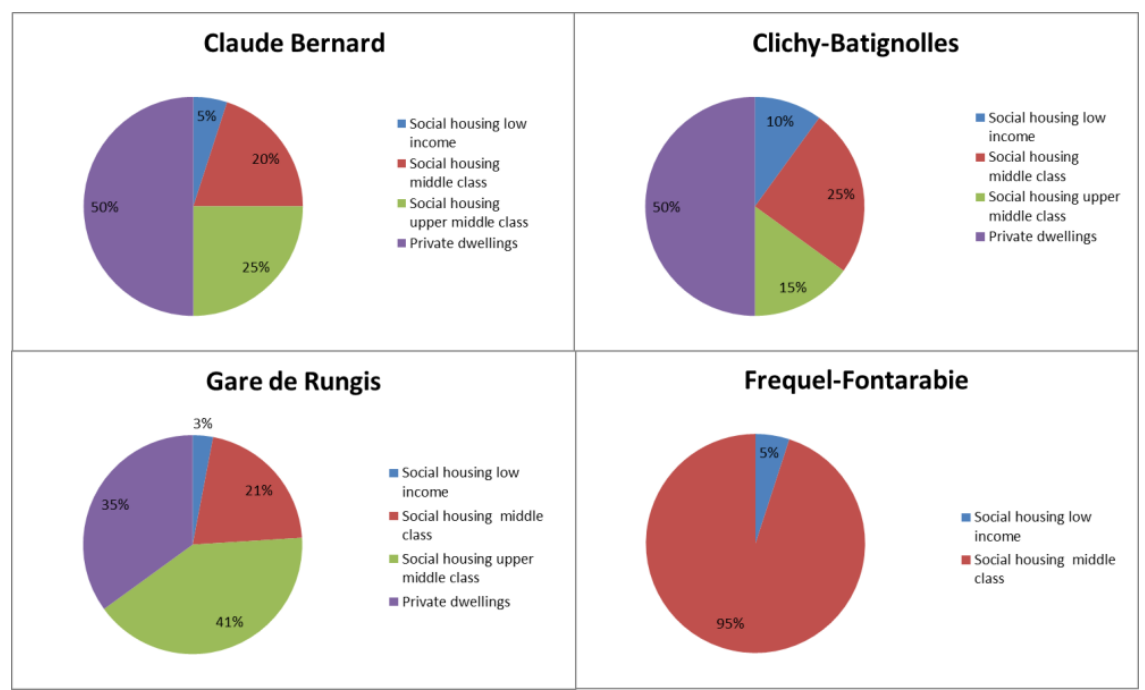

Figure 3. Share of social housing by category in selected Paris eco-quartiers

Source: Machline et al., 2016.

Figure 3 shows that the share of social housing units for low income families is minimal in all eco-quartiers: 5\% in Claude Bernard, 10\% in Clichy- Batignolles, 3\% in Gare de Rungis and 5\% in Frequel Fontarabie. According to Machline et al. (2016), all eco-quartiers are located in areas that already include a high number of social housing units ( $90 \%$ or more such units). Moreover, no eco-quartier was planned in areas lacking social housing (Machline et al., 2016), to increase its supply.

According to Machline et al. (2016), four out of six eco-quartiers were planned in the lowest socio-economic status block areas and arrondissements (Note 17) (Category 3 - 13th and 18th-20th). According to a Paris Municipality Planning Unit representative (personal communication, 13 April 2016), the eco-quartiers aimed to increase the share of private dwellings and upper middle-class social housing, to attract higher income residents.

The Claude Bernard eco-quartier included 50\% private dwellings and 25\% middle-class social housing, and was thus designed primarily for middle-class residents. In fact, the neighborhood's share of low-income social housing is only 5\%, whereas in the statistical block areas surrounding it the share exceeds $90 \%$. The 19th arrondissement as a whole includes $35 \%$ social housing while the average annual household income is less than $€ 30,000$ - very low compared to the Parisian average (Machline et al., 2016). Thus, at least $75 \%$ of the housing units in the eco-quartier will be unaffordable to the local $\left(19^{\text {th }}\right.$ arrondissement $)$ population. According to the social housing company representative (personal communication, 2015) "the shares of social housing categories were decided upon by the municipality". 


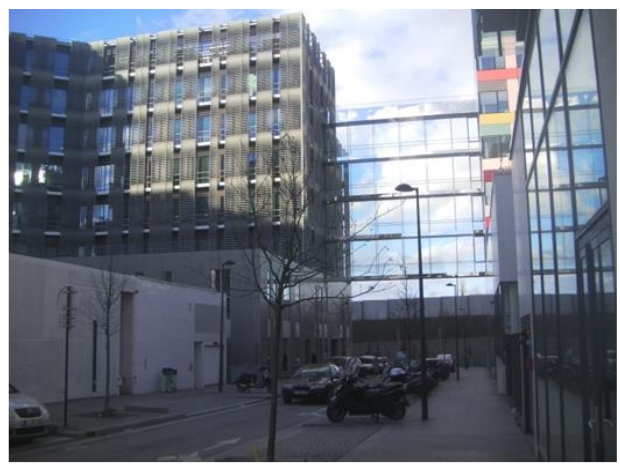

Offices building Pictures: Machline, 2014

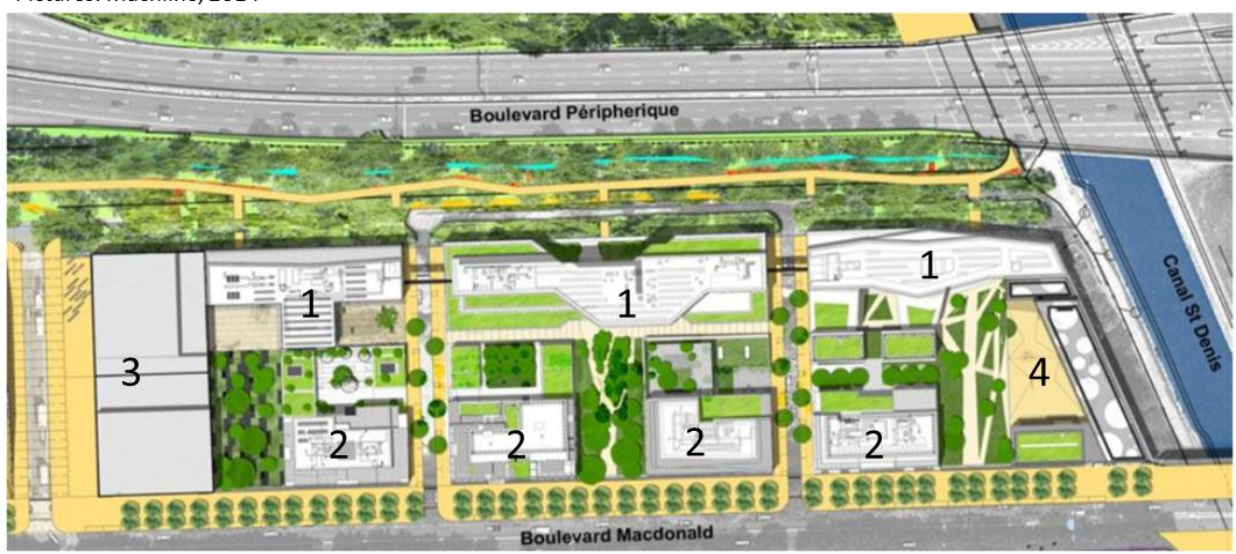

1- Offices (41 000m2); 2-Housing (27 $000 \mathrm{~m} 2)$, Elder house (6200 m2), Commerce (7000 m2); 3- leisure (10 000m2); 4- Public equipment

Figure 7. The Claude Bernard eco-quartier

Source: Machline et al., 2016.

Dwellings in Claude Bernard, public or private fail to provide 'affordable housing prices' (as stipulated in the certification file) to pre-existing residents of the 19th arrondissement. According to the Paris Municipality Planning Unit and housing authority (2015), the aim was to attract a wealthiest population: "The aim is to balance the socio-economic level of the population" (Head of the Housing Authority of Paris, 2015). According to a representative of the developer (2015), veteran residents were strongly encouraged to move out.

The private dwellings in Claude Bernard were sold at $4 \%$ less than the average 19th arrondissement prices for new housing. Moreover, according to the manager of the planning company (2015): "At the beginning it was not easy to sell the apartments. The first home buyers were very brave to move into a neighborhood where they were exposed to prostitution and drugs on a daily basis!"

The situation is similar for the Gare de Rungis eco-quartier $\left(13^{\text {th }}\right.$ arrondissement), where the share of social housing is $65 \%$ but the upper middle-class public housing units constitute $63 \%$, while the low-income units are only $4.4 \%$ of the social housing stock (Figure 3). In the Frequel-Fontarabie eco-quartier, which included 27 of the 1030 Parisian substandard buildings (Observatory for Building Degradation Prevention in Paris, 2012), 95\% of the social housing is meant for the middle-class (Figure 3). However, before the establishment of the eco-quartier, all of the housing stock was for low income people (Paris Housing Authority, 2014). Thus, 38\% of the social housing built in Paris since 2001 was intended for the upper-middle-class, which did not match the demand: among the 100,000 applicants for social housing in Paris, 75\% earned below the low-income housing limit, while only $4 \%$ could apply for upper middle-class housing (APUR, 2007). Nowadays, low-income public dwellings represent only 15\% of the social housing built in Paris (Clerval, 2010). At the city scale, between 2001 and 2013, the newly built social housing consisted of $25 \%$ for low income and $37 \%$ for middle income, while the share for the upper-middle-class was even slightly larger, at $38 \%$. This city scale ratio is substantially lower than that of the eco-quartiers (Gare de Rungis: 63\%, Claude Bernard: 50\%) - and to the extent that such social housing promotes gentrification in the poorest districts of Paris, the eco-quartiers themselves foster 
'eco-gentrification', at the expense of the poor. While working-class households face growing difficulties in finding public or private dwellings in Paris, public policies have only improved housing conditions for those who can afford to stay in the city or move into it (Clerval \& Fleury, 2012).

\section{A remote suburb: Bretigny Sur Orge}

The Clause Bois Badeau eco-quartier is located in the small municipality of Brétigny sur Orge, 35 kilometers south of Paris, in the department of Essonne, in the Ile De France region (Note 18), on line C of the RER.

In the second half of the 20th century, Brétigny-sur-Orge, like most municipalities in the Paris region, experienced rapid population growth, going from 3,673 residents in 1946 to more than 12,000 in 1968 and 21,650 in 1999 . The latest censuses show that in the next decade the population became stable, attaining 21,837 inhabitants in 2007. The territory of Brétigny-sur-Orge remains mostly farmland, cultivated by the Clause farming company. In 2000 eight farms remained active, while in 2006136 people still worked in agriculture. Unemployment was low (8.4\%) in 2006, but $17 \%$ of employees worked on precarious contracts. Employees and workers are widely represented in the commune, while managers, craftsmen and traders are fewer than in the rest of the department. However, there are disparities, as $55 \%$ of the tax households paid solidarity tax on wealth (Note 19), while only $67.9 \%$ of the households paid income tax (the average net tax income in the municipality being about 25,000 euros per household). In 2006, only 51.6\% of the Brétignolais owned their dwellings, while $25.7 \%$ lived in HLM's. In 2011, the median tax revenue per household was $€ 36,0000$, and most (76.8\%) of the population worked in another municipality. Bretigny Sur Orge can be defined as a middle-income municipality (the national median income being $€ 20,369$ - INSEE, 2014).

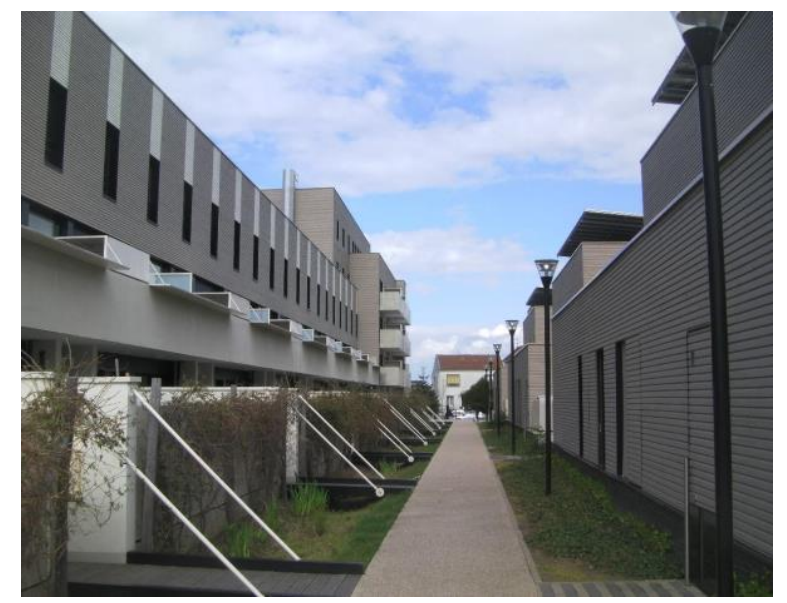

Figure 8. The Clause Bois Badeau eco-quartier

Source: Machline, 2016.

The eco-quartier will include 2,400 housing units, $30 \%$ of them - social housing. The total population in Bretigny is 23,000 habitants, and thanks to the eco-quartier it is projected to reach 30,000 within 15 years. In 2016, 700 housing units were built, $46 \%$ of them social housing (for the first phase). The commune of Brétigny sur Orge has $32 \%$ social housing units. The eco-district was built on 42 hectares, mostly agricultural fields, and project development began in 2006. So far, the $46 \%$ share of social housing includes $5 \%$ for low-income households and $32 \%$ for middle-class households. 


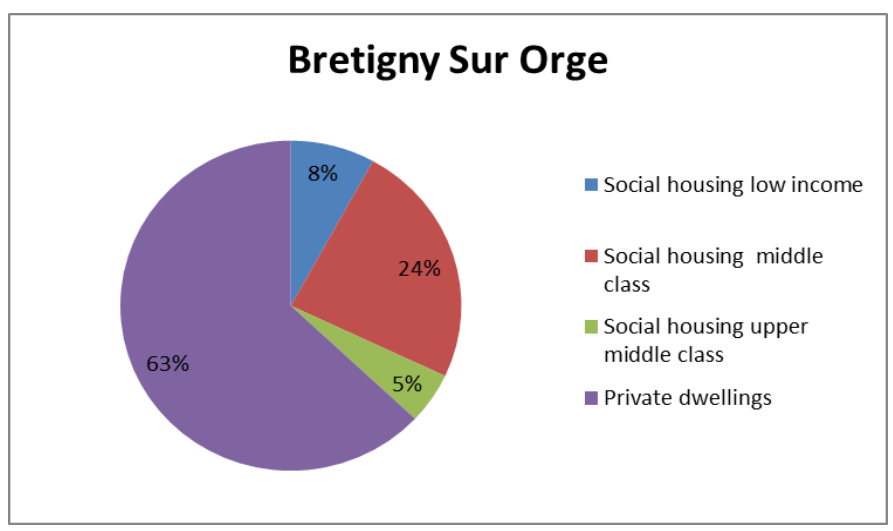

Figure 9. Housing distribution in the Clause Bois Badeau eco-quartier

Source: Municipality of Bretigny Sur Orge, 2016.

According to the development company's project manager, the reason for building $46 \%$ social housing - rather than $30 \%$ as originally planned - was the 2008 real estate crisis. Some promoters had to cancel their participation, and thus, to implement the project, the socialist-led municipality decided to plan more social dwellings, as social housing companies are funded by the State. The project, which was to start with private apartments, began with social housing units. However, according to the Head of the Planning Unit of Bretigny sur Orge, the new neighborhood's start with social housing gave it a bad image in the town.

Bretigny is mainly composed of low-density neighborhoods; the population was scared that Clause Bois Badeau would become a "dangerous vertical slum", like others in the Essonne department, for example in Corbeil-Essonnes, Evry and Grigny. There was a feeling that the entire municipal budget would be spent on this new neighborhood. The loss of the main green and open spaces of Bretigny was also hard to accept. According to the Development Company Manager: "The owner of the private rental buildings encountered difficulties in finding renters - for instance, the cheapest four room unit (100 sq.m. on average) costs 2,400 euro/month and should not be above 1,800 to be affordable for a family." Apartments in the new neighborhood (about 3,500 euro/sq.m.) are cheaper than those around it (3,800 euro/ sq.m.). Thus, the building of a 'green' neighborhood in Bretigny Sur Orge had no gentrifying effect. The newly elected right-wing municipal team (in 2014) canceled a social housing operation before its implementation and, since the election, only private dwellings have been designed. The aim is to attract a more affluent population and even plan single-family house projects (Development company project manager, personal communication 21/04/2016).

According to the development company's project manager, most home buyers are young families from Bretigny or surrounding cities, purchasing their first apartment. The municipality wanted at least $60 \%$ of the homebuyers to be residents (to limit the share of outside investors). Thus, the real estate companies selling the apartments were asked to prevent that share from rising above $40 \%$ (Head of the Urbanism Unit, Municipality of Bretigny, personal communication 18/04/2016).

Within the eco-quartier, a central urban heating network was installed, consuming wood pellets (considered cleaner than other heating fuels). However, according to the Head of the Urbanism Unit, the residents complain of thermal discomfort and construction defects. Most buildings fail to attain the planned energy efficiency, and even if overall energy consumption is lower than for conventional buildings, the residents' monthly bills are not lower, as the maintenance cost of the 'greener' heating system is higher than that of conventional heating based on natural gas. To avoid construction defects, the municipality has tried to ensure that the promoters improve their inspection skills and the Bretigny Mayor makes it a point to be present for each building inauguration and inform the promoters that "if there are construction defects, they will hear from him" (Head of the Urbanism unit, municipality of Bretigny, personal communication 18/04/2016).

\section{A remote periphery: Reims}

Reims, in the Marne department of the Grand Est region of France (previously in the Champagne-Ardenne region), lies $129 \mathrm{~km}$ east-northeast of Paris. The 2013 census recorded 182,592 dwellers in the city proper and 317,611 inhabitants in its metropolitan area. Historically, the Notre Dame de Reims cathedral has been the place of coronation of French kings. The bubbling Champagne, produced in the Reims region since the end of the 17th century, has become one of its economic assets. The city of Reims has undergone rapid economic growth 
between 1960 and 1975, due to the establishment of new industries (some of them owned by IKEA). The period was marked by notable spatial expansion and a 54\% demographic growth rate (from 131,000 in 1954 to 200,000 in 1975). Like most French cities, Reims subsequently experienced both economic and demographic stagnation.

The arrival of the TGV high-speed train in 2007 provided a new boost to growth, putting Reims at just 45 minutes from Paris, 35 minutes from Marne-la-Vallée (Note 20) and 30 minutes from the Roissy-Charles de Gaulle International Airport. Reims would like to host Parisian companies wishing to relocate to lower operating costs. A new tramway line was built in 2011, running through the Reims city center and serving its two most important neighborhoods, the Orgeval district in the north and the Red Cross district in the south. Notwithstanding these growth enhancing steps, Reims still belongs to the poorest third of French municipalities.

The construction of large housing projects began in the 1960s. One of the most important HLM neighborhoods is the Croix Rouge district (divided into three sectors: Nord, Pays de France and Croix du Sud), launched in 1967. Located in the south-west of the city, this district had 25,000 inhabitants by 2010, almost as many as the entire city in 1962. The faculties of Law and Letters were established in the north of the Croix Rouge District. The Faculties of Medicine and Pharmacy are also located in the district, at the edge of the University Hospital Center. These last two public facilities are in the Pays de France sector, while the Faculties of Law and Letters are in the Northern sector (University sector).

The Pays de France eco-quartier: Refurbishing a low-income social housing neighborhood The Pays de France eco-quartier is located in the Croix Rouge district (with a population of 20,000) and has about 4,000 residents. It is part of a larger urban renewal plan drawn in 2004 and implemented from 2009 to 2015. The project was funded by the ANRU, the European fund FEDER, Caisse des Dépôts et Consignations, the Champagne regional council, the Marne department, the Reims municipality and the Foyer Remois social housing company.

Historically the Pays de France district was a social housing neighborhood, built like many others in 1960-1970. The housing company is FOYER REMOIS. The Pays de France neighborhood is the most fragile area of the Croix Rouge district, with an impoverished population and a severe lack of local businesses. A study by the municipality in 2006 lists the following dysfunctions:

- The urban design is inappropriate, even obsolete (slab planning due to functionalist conception), with a separation between pedestrian and car traffic;

- Shops and services are lacking;

- Public and private open spaces are in bad shape;

- There is no functional diversity (almost only housing);

- The population is fragile, with higher rates of families in economic difficulty and of young people below 25 years of age, than other neighborhoods in Reims (Note 21);

- A feeling of insecurity is worsened by intercultural and intergenerational coexistence (Note 22);

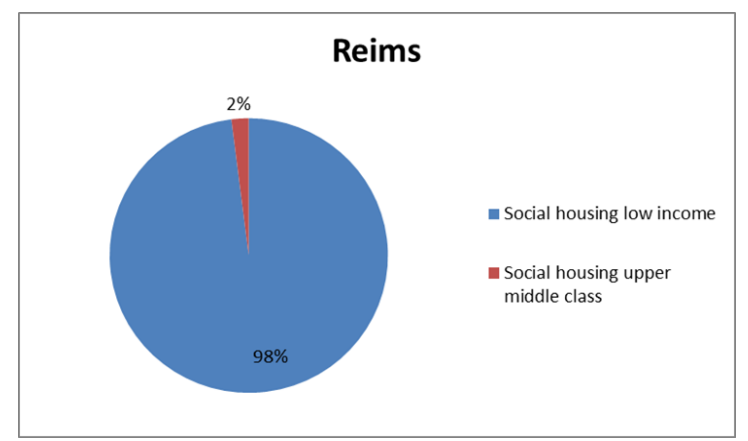

Figure 5. Social housing distribution in the Pays de France neighborhood in Reims

Source: Municipality of Reims, 2016.

The neighborhood only included low-income social housing units and has been refurbished with ANRU (Note 23) subsidies. Among the 530 apartments, 158 were torn down and some residents were relocated in other social housing neighborhoods in Reims. According to the certification file, to promote social mix, 45 units for upper middle class and 23 social dwellings for private ownership were to be included. However, according to the Head of Reims City and Housing Policy Department and the Head of Social and Urban Development Department of the Foyer Remois social housing company (19.08.2016, personal communication), only 17 upper middle-class 
housing units were built and remained empty, as their rent is even higher than in the private sector. Furthermore, the image of the neighborhood detracted from the apartments' attractiveness. "We made upper middle-class apartments, but it was no success. Still, we believe that the neighborhood's great location will attract new populations. We are optimistic. At present, there is no population renewal. Until we renovate the entire district (Croix Rouge), its bad reputation will linger on. It will probably take an entire generation to change the image. Even if the eco-quartier buildings are high standard, they are surrounded by very low-quality buildings. The social mix aspect was one of the weaknesses of our application. We could not satisfy all requirements, given that we first planned the projects and only then applied for the label." (Head of Reims City and Housing Policy Department, personal communication, 2016).

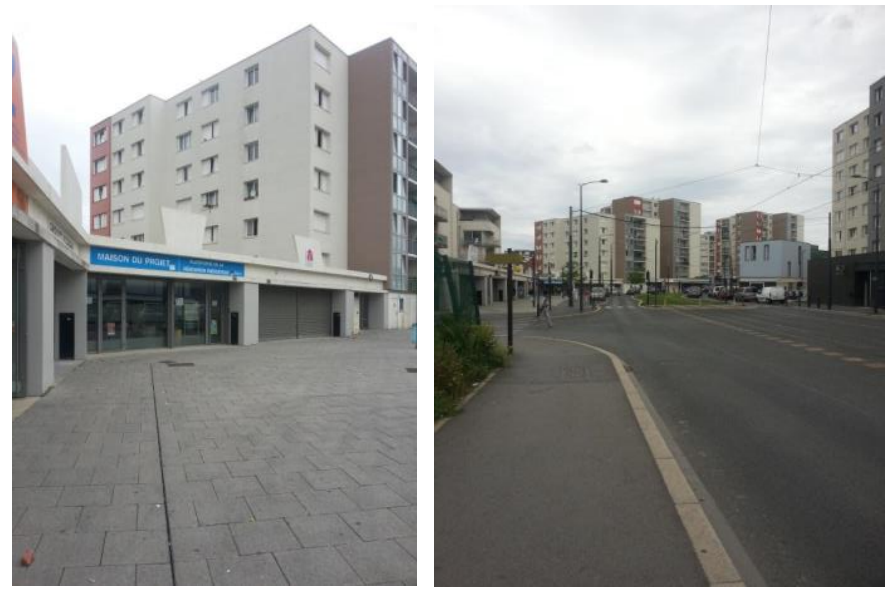

Figure 6. The Pays de France Eco-quartier

Photo: Machline, 2016.

All buildings received the BBC certification. However, to pay for the refurbishment, the social housing company raised rents by about 50 euro/month. According to the Head of the Social and Urban Development Department of the Foyer Remois social housing company, "thanks to the BBC certification requirements, the final energy consumption decreased by 30-50\%. Thus, even if the rent increased, the residents pay little more than before, 5 euros more on average). According to the Head of Reims City and Housing Policy Department, when the rent increase is too high (as it has been for a few families in Pays de France), the municipality has subsidized it during the first four years (20 Euros/month during the first year, then dropping to 15, 10 and 5). In Reims, the eco-district had no gentrifying effect and brought 'green' housing to the poor.

\section{Discussion}

In France, which remains one of Europe's most centralized states, national regulations have played a decisive role in the implementation of 'green' building. Even the locally implemented urban eco-districts may be seen as an initiative of the State, which viewed the eco-quartier label as a way to regulate local 'green' neighborhood initiatives (Head of Sustainable Planning Unit, French Ministry of Housing, the Equality of Territories and Rurality, personal communication, 2015). Each of the three main stakeholders involved in eco-quartier design, promotes his own agenda: (1) the E.U. aims to reduce greenhouse gas emissions (through 'green' building), (2) The French state implements its social housing regulations and, (3) the municipalities wish for 'gentrification (to collect more taxes and reduce social expenses) but often also pursue wider construction activities and population growth. These divergent agendas may explain the disjunction between policy discourse and implementation. There is a national funding system for subsidizing public housing construction (the SRU law), and more than half the environmentally-certified apartments are defined as public social housing under that scheme. Additionally, as an EU country, France benefits from European funds earmarked for improving the energy performance of public social housing, as part of the European Energy Performance of Buildings Directive-EPBD (2002; 2010). One way to implement the EPBD was to establish a national framework for eco-districts, whereby municipalities received budgets from the European Union (through the State) subsidizing the construction of 'green' and affordable apartments. In France, the Eco-quartier framework stipulates social diversity. As mentioned, its initiators emphasize that proposing measures promoting social mix is a prerequisite for project approval. According to eco-district program requirements, the local authority had to verify (until 2015) "whether housing location and prices are appropriate to household's income" (Certification file, 2015) (Note 24). In contrast to the LEED ND certification, in the French label social mix and housing affordability are mandatory 
elements. Thus, the eco-quartiers are mandated to have at least $40 \%$ public social housing. One might say that the French state authorities want to build 'green' and affordable housing. However, local decision-makers manipulate funding methods, with the status (subsidized housing for low, middle, upper middle classes) of the accommodation and the size of the apartments, while attempting to generate some social diversity (some apartments are rental social housing). Moreover, regulations specify that municipalities in deficit must include 'HLM' construction in their urban development projects. Thus, more than half the BBC apartments are social housing. However, as the law fails to specify the shares of social housing types, the numbers of units for low-income families are very small in attractive locations, like Paris (5\% average). More generally, in affluent cities, where property prices are high (like in Paris, its well-to-do suburbs and some large cities), municipalities build eco-quartiers in substandard neighborhoods, to attract middle class families. In average cities, like Bretigny sur Orge, municipalities may implement more social housing than planned, especially if they are socialist municipalities and thus less reluctant to host low-income populations in eco-quartiers. In the poorest French towns, like Reims, the eco-quartiers will improve living conditions, but remain irrelevant to the social mix. In other words, poor and middle-income municipalities build a large share of social housing in their eco-quartiers, due to a lack of private investors willing and able to invest their own capital in such municipalities. Attracting well-to-do residents is only possible in Paris, its closer suburbs and other affluent cities, where the share of low-income populations in eco-quartiers is minimal.

In the last revision of the Eco-quartier label guidelines (2016) (Note 25), the ministry deleted the requirement that the local authority verify "whether housing location and prices are appropriate to household's income" (Certification file, 2015), as it was considered "too complicated to fulfill for the municipalities".

Most eco-quartiers are located in average income cities and none in the wealthiest ones (which need no eco-district to attract middle class residents). However, we find some eco-quartiers in Paris and in some close suburban localities (such as Boulogne) where the annual income is well above the median of 20.150 euro/year (see Table 2 in Appendix).

\section{Conclusion}

France entered the Eco-Quartier planning process in 2008, after the Northern European Countries, but since the early 2000s, more than 1,000 municipalities have applied for the eco-quartier label. The multiplication of 'green' neighborhood projects shows a growing concern of French authorities for the environment, as well as a drive among municipalities to obtain funds for construction purposes.

The specificity of the French eco-districts remains the social mix requirement, countering socio-spatial segregation. Avoiding the repetition of past 'mistakes' (such as concentrating poor people in large HLM projects) is essential in the view of French planning authorities. The eco-quartiers are usually located in substandard districts of large cities or average income municipalities, and their role is to attract middle class people, seen as guarantors of social cohesion. However, social mix goals are barely reached. In affluent cities where property prices are high (like Paris, its suburbs and some large cities), the municipalities build eco-quartiers in substandard neighborhoods to attract middle class families. In average cities (such as Bretigny Sur Orge), some municipalities have implemented more social housing than planned, to obtain State subsidies and loans for developers (thus the greening was motivated by budget considerations) - but can still privilege the middle class in that housing's allocation. The high share of social housing is due to these municipalities' difficulties in attracting middle-class customers to buy the private apartments and to their willingness to accept some poor residents, if that's what it takes to encourage further construction. In the poorest French towns, like Reims, the eco-quartiers will improve living conditions in substandard neighborhoods but remain irrelevant to social mix.

Attracting well-to-do populations is only possible in Paris, including some of its closer suburbs like Levallois Perret and Boulogne, and other affluent cities (for example Bordeaux), where the share of low-income populations in the eco-quartiers will be minimal. In the wealthiest large cities, 'green' housing has a gentrifying effect. However, in the municipalities of middle and lower-income (such as Mulhouse or Tours), eco-districts cause no gentrification.

\section{References}

Andersson, R., Musterd, S., Galster, G., \& Kauppinen, T. M. (2007). What mix matters? Exploring the relationships between individuals' incomes and different measures of their neighborhood context. Housing Studies, 22(5), 637-660. https://doi.org/10.1080/02673030701474602

Atkinson, R. (2008). Commentary: Gentrification, Segregation and the Vocabulary of Affluent Residential Choice. 
Urban Studies, 45(12), 2626-2636. https://doi.org/10.1177/0042098008097110

Authier, J. (2007). Les « quartiers » qui font l'actualité. Espaces et sociétés, (1), 239-249. https://doi.org/10.3917/esp.128.0239

Bacqué, M. H., Fijalkow, Y., Launay, L., \& Vermeersch, S. (2010). Social Mix Policies in Paris: Discourses, Policies and Social Effects. International Journal of Urban and Regional Research, 35(2), 256-273. https://doi.org/10.1111/j.1468-2427.2010.00995.x

Baudin, G. (2001). La mixité sociale: Une utopie urbaine et urbanistique. revue du CREHU, p. 12.

$\begin{array}{lllll}\text { BBC-Effinergie (n. } & \text { website. } & \text { Retrieved } & \text { from }\end{array}$ https://www.effinergie.org/web/index.php/les-labels-effinergie/bbc-effinergie

Blanc, M. (2004). The changing role of the state in French housing policies. European Journal of Housing Policy, 4(3), 283-302. https://doi.org/10.1080/1461671042000307260

Bulkeley, H., \& Betsill, M. (2011). Revisiting the urban politics of climate change. Environmental Politics.

Charlot-Valdieu, C., \& Outrequin, P. (2009). L'urbanisme durable: Concevoir un écoquartier. Le Moniteur. France.

Clerval, A., \& Fleury, A. (2012). Urban Policy and Gentrification. A Critical Analysis Using the Case of Paris. Lidia Diappi. Emergent Phenomena in Housing Markets. Gentrification, Housing Search, Polarization, 21, 151-170. https://doi.org/10.1007/978-3-7908-2864-1_7

De Chastenet, C., Belziti, D., Bessis, B., Faucheux, F., Le Sceller, T., Monaco, F. X., \& Pech, P. (2016). The French eco-neighborhood evaluation model: Contributions to sustainable city making and to the evolution of urban $\begin{array}{lllll}\text { practices. Journal of } & \text { Environmental }\end{array}$ https://doi.org/10.1016/j.jenvman.2016.03.036

De Vaus, D. A. (2001). Research design in social research. London Sage Publications.

Donzelot, J., Mevel, C., \& Wyvekens, A. (2003). Faire société. La politique de la ville aux États-Unis et en France. Paris, Seuil, p. 364.

Emelianoff, C. (2011). La ville durable: l'hypothèse d'un tournant urbanistique en Europe. L'information Géographique, 71, 48-65. https://doi.org/10.3917/lig.713.0048

Flint, J., \& Kearns, A. (2006). Housing, Neighborhood Renewal and Social Capital: The Case of Registered Social Landlords in Scotland. European Journal of Housing Policy, 6(1), 31-54. https://doi.org/10.1080/14616710600585716

Grimm, N., Faeth, S., Golubiewski, N., Redman, C., Wu, J., Bai, X., \& Briggs, J. (2008). Global Change and the Ecology of Cities. Science, 319(5864), 756-760. https://doi.org/10.1126/science.1150195

Kearns, A., \& Mason, P. (2007). Mixed tenure communities and neighborhood quality. Housing Studies, 22(5), 661-691. https://doi.org/10.1080/02673030701474628

Kirszbaum, T. (2007). Mixité sociale dans l'habitat: Revue de la littérature dans une perspective comparative. Paris, La Documentation française, p. 141.

Lapeyronnie, D. (2008). Ghetto Urbain. Ségrégation, Violence et Pauvreté en France Aujourd'hui, Paris: Laffont.

Lelevrier, C. (2006). Les mixités sociales. Problèmes politiques et sociaux, n²9.

Levy-Vroelant, C. (2007). Héberger. In M. Ségaud, J. Brun, \& J. C. Driant (Eds.), Dictionnaire de l'habitat et du logement (p. 451). Armand Colin.

Machline, E., Pearlmutter, \& Schwartz, M. (2016). Parisian eco-districts: low energy and affordable housing? Building Research \& Information, 1-17. https://doi.org/10.1080/09613218.2016.1258852

Massey, D. (1881). Social Class and Ethnic Segregation: A Reconsideration of Methods and Conclusions. American Sociological Review, 46(5), 641-650. https://doi.org/10.2307/2094945

Maurin. (2018). Rapport sur la pauvreté en France, première édition - 2018. Observatoire des inégalités et Compas, édité par l'Observatoire des inégalités, octobre 2018.

MoESDTH. (2009). Dossier de presse sur la lère conférence nationale sur la ville durable. Retrieved from http://www.developpementdurable.gouv.fr/04-11-09-1ere-conferencenationale.html

Pan Ké, J. L. (2012). Perception of Insecurity in French Poor Neighborhoods: Racial Proxy or Pure Discrimination 
Hypotheses? Urban Studies, 49(3), 505-525. https://doi.org/10.1177/0042098011402237

Scott, J. (1991). Social Network Analysis: a Handbook. Sage Publications.

Simon, P. (1995). La politique de la ville contre la ségrégation. Ou l'idéal d'une ville sans divisions. Les Annales de la recherche urbaine, (68-69), 27-33. https://doi.org/10.3406/aru.1995.1895

Tunstall, R., \& Fenton, A. (2006). In the mix: a review of mixed income, mixed tenure and mixed communities. Housing Corporation, Joseph Rowntree Foundation/English Partnerships.

UN-Habitat. (2011). Global Report on Human Settlements: Cities and Climate Change. UN-Habitat, Nairobi, Kenya. https://doi.org/10.4324/9781849776936

Yin, R. K. (2009). Case Study Research: Design and Methods. Sage Publications.

Yin, R. K. (2011). Applications of Case Study Research. Sage Publications.

\section{Appendix}

Appendix 1. The Eco-quartier framework

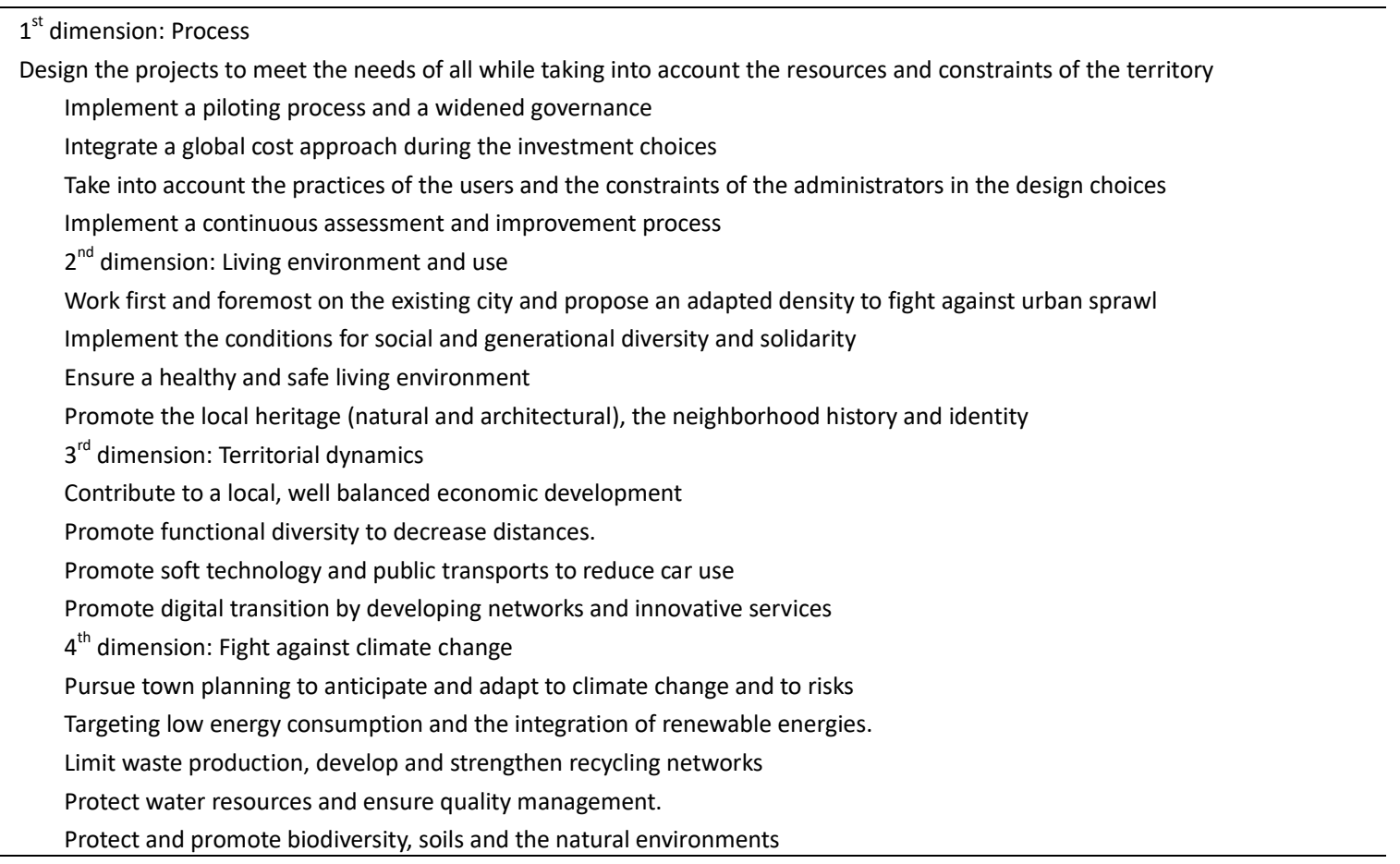

Source: French Ministry of Housing, 2009.

Appendix 2. Eligibility and rents in public social housing

\begin{tabular}{lccc}
\hline Target & Monthly net income limit for family of 3 & \multicolumn{2}{c}{ Subsidized monthly Rent ceiling } \\
\cline { 2 - 3 } & Paris & $\begin{array}{c}\text { Elsewhere } \\
\text { France }\end{array}$ & \\
\hline Low income & $€ 2500$ & $€ 1800$ & $€ 4.22$ to $€ 5.8 / \mathrm{m} 2$ \\
Middle-class & $€ 4100$ & $€ 2900$ & $€ 4.73$ to $€ 6.9 / \mathrm{m} 2$ \\
Upper-middle class & $€ 5400$ & $€ 3800$ & $€ 7.11$ to $€ 12.8 / \mathrm{m} 2$ \\
\hline
\end{tabular}

Source: L'Union Nationale pour l'Habitat, 2011.

Appendix 3. Eco-quartiers income and housing distribution

\begin{tabular}{|c|c|c|c|c|}
\hline \multirow[t]{2}{*}{ Municipality } & \multirow[t]{2}{*}{ Eco-quartier name } & Annual average & Housing distribution (\%) & \multirow{2}{*}{$\begin{array}{c}\text { Share of social } \\
\text { housing at } \\
\text { municipal level }\end{array}$} \\
\hline & & Private & Social & \\
\hline
\end{tabular}




\begin{tabular}{|c|c|c|c|c|c|c|c|}
\hline & & & & Low-icome & Middle-class & Upper middleclass & in 2015 (\%) \\
\hline Boulogne & $\begin{array}{c}\text { Billancourt, } \\
\text { Trapèze }\end{array}$ & 61121 & 70 & 1.2 & 18 & 10.8 & 14 \\
\hline Bretigny Sur Orge & Clause Bois Badeau & 36000 & 63 & 8 & 24 & 5 & 25 \\
\hline Forcalquier & $\begin{array}{l}\text { ÉcoQuartier } \\
\text { historique }\end{array}$ & 30631 & & & & & \\
\hline Grenoble & Bouchayer Viallet & 31943 & 65 & 5 & 20 & 10 & 21.9 \\
\hline Grenoble & ZAC de Bonne & 31943 & 60 & 5 & 20 & 15 & 21.9 \\
\hline Hédé-Bazouges & Les Courtils & 35609 & & & & & \\
\hline La & Quartier & 48689 & & & & & \\
\hline $\begin{array}{l}\text { Chapelle-sur-E } \\
\text { rdre }\end{array}$ & Perrières & & & & & & \\
\hline La Rivière & Coeur de Bourg & 30455 & & & & & \\
\hline Lille & $\begin{array}{c}\text { Les Rives de la } \\
\text { Haute-Deûle }\end{array}$ & 30188.25 & 70 & 6 & 14 & 10 & \\
\hline Lyon & La Duchère & 38144.33 & 45 & 20 & 25 & 10 & 19.7 \\
\hline Mulhouse & Wolf Wagner & 28141.01 & 0 & 80 & 20 & 0 & \\
\hline Paris & ZAC Claude Bernard & 54664.52 & 50 & 5 & 20 & 25 & 19 \\
\hline Paris & Fréquel-Fontarabie & 54664.52 & 0 & 5 & 95 & 0 & 19 \\
\hline $\begin{array}{l}\text { Saint-Pierre-de-la- } \\
\text { Réunion }\end{array}$ & La Ravine Blanche & 18971 & & & & & \\
\hline $\begin{array}{l}\text { Sainte-Croix-aux- } \\
\text { Mines }\end{array}$ & Les Coccinelles & 31173 & & & & & \\
\hline Mulhouse & Lefebvre & 28141 & 0 & 42 & 20 & 38 & \\
\hline Bordeaux & Ginko - Les Berges du & 34930 & & & & & \\
\hline & Lac & & 66.2 & 7.5 & 19.6 & 6.7 & 16.8 \\
\hline Longvic & Les Rives du Bief & 30975 & & & & & \\
\hline Tours & Monconseil & 29691 & 67 & 5 & 23 & 5 & \\
\hline Reims & $\begin{array}{l}\text { Croix-Rouge Pays de } \\
\text { France }\end{array}$ & 30568.57 & 0 & 98 & 0 & 2 & \\
\hline Morez & $\begin{array}{l}\text { Villedieu-Le Puits } \\
\text { Programme de }\end{array}$ & 32237 & & & & & \\
\hline Nanterre & Hoche & 36749 & 60 & 2 & 18 & 20 & \\
\hline Paris & Boucicaut & 54664 & 50 & 5 & 20 & 25 & 19 \\
\hline Prades-le-Lez & $\begin{array}{c}\text { Projet Horizons - } \\
\text { Viala Est }\end{array}$ & 45674 & & & & & \\
\hline Les Forges & La Ferme Forgeronne & 19567 & & & & & \\
\hline Balma & Vidailhan & 51008 & & & & & \\
\hline Blagnac / Beauzelle & Andromède & 37856 & & & & & \\
\hline Graulhet & $\begin{array}{l}\text { Les Résidences du } \\
\text { Parc }\end{array}$ & 26307 & & & & & \\
\hline Mons-en-Baroeul & Le Nouveau Mons & 29758 & & & & & \\
\hline Angers & ZAC Desjardins & 30238 & 80 & 2 & 8 & 10 & \\
\hline Changé & La Barberie & 27510 & & & & & \\
\hline Grenoble & Blanche-Monier & 31943 & 50 & 0 & 20 & 30 & \\
\hline Saint-Brieuc & Quartier de l'Europe & 28883 & 0 & 60 & 23 & 17 & \\
\hline Mantes-la-Jolie & $\begin{array}{l}\text { Quartier du Val } \\
\text { Fourré }\end{array}$ & 30334 & 100 & 0 & 0 & 0 & \\
\hline Levallois-Perret & Quartier Eiffel & 57630 & & & & & \\
\hline Montreuil & $\begin{array}{c}\text { Quartier Bel Air - } \\
\text { Grands Pêchers }\end{array}$ & 34061 & & & & & \\
\hline Ivry-sur-Seine & ZAC du Plateau & 32000 & & & & & \\
\hline Montpellier & Les Grisettes & 29133.15 & & & & & \\
\hline Montpellier & Parc Marianne & 29133.15 & & & & & \\
\hline
\end{tabular}

Source: INSEE, 2014. Indicateurs de structure et de distribution des revenus en 2011' Revenus fiscaux localisés des ménages. Retrieved from website: https://www.insee.fr/fr/statistiques/1893301 Original data, 2016. 


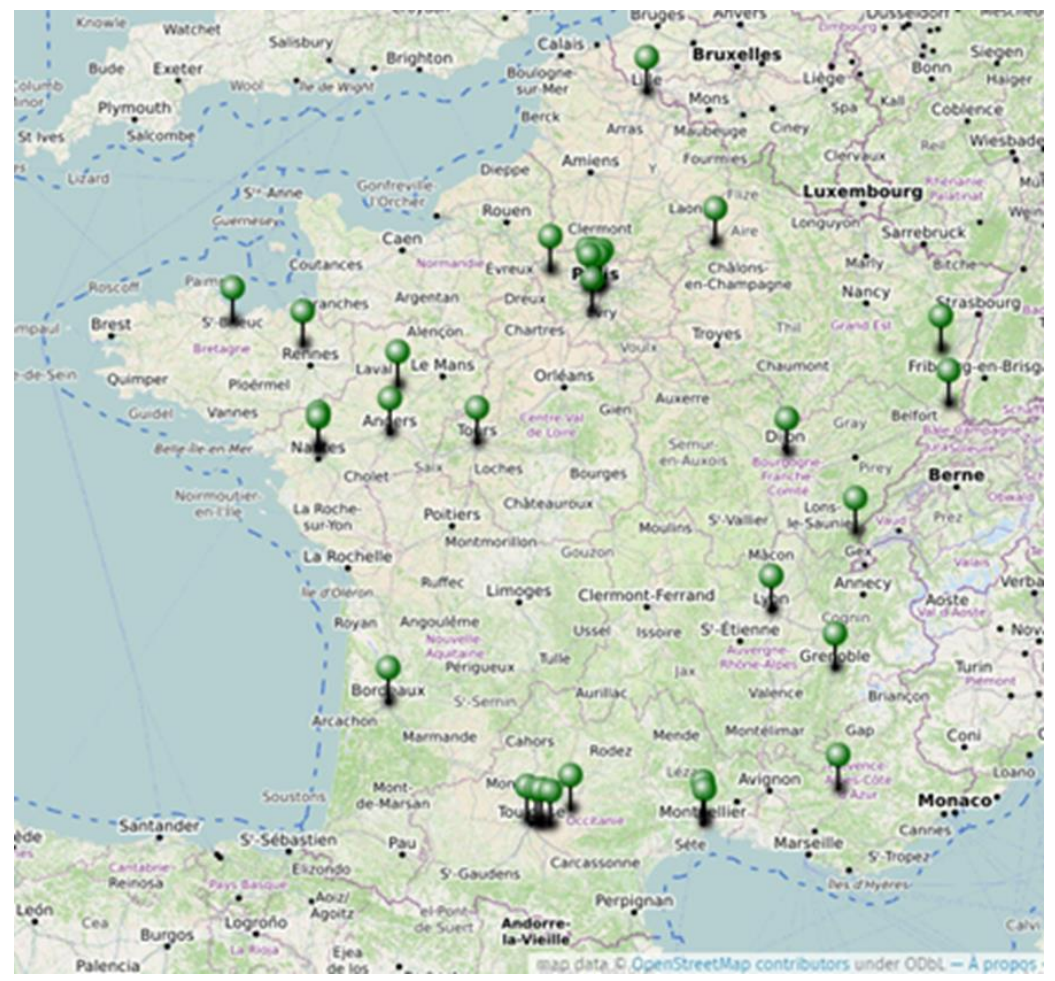

Appendix 4. Eco-districts that received the certification by 2016

Map: Machline, 2019.

Most eco-quartiers are located in former textile industrial localities (besides Paris). The center of France, with former metallurgic industries, is not represented.

\section{Notes}

Note 1. French framework act on town planning and urban renewal, 2003 (Programme National de Rénovation Urbaine).

Note 2. After the European Union climate and energy package was adopted in 2008, the European Commission launched the Covenant of Mayors to endorse and support the efforts deployed by local authorities in the implementation of sustainable energy policies.

Note 3. Copenhagen received the 2014 C40 Cities-Siemens City Climate Leadership Award for its path towards climate neutrality by 2025 (see http://cityclimateleadershipawards.com/wp-content/uploads/2014/06/Copenhagen-Climate-Close-Up.pdf) and was named European Green Capital for 2014; Stockholm was the first European Green Capital in 2010. Freiburg was awarded the Academy of Urbanism's European City of the Year Award in 2010. Among Malmö's awards are: a 2009 UN-Habitat Scroll of Honor award for sustainable development; a 2010 award from the Building Exchange for the Best Master Plan for the Western Harbor; a 2010 United Nations World Habitat Award for the revitalization of Augustenborg. In 2012 Malmö was a finalist for the European Green Capital designation.

Note 4. Such estimates are highly variable: for exemple for passive buildings, 'the extra-cost represents $7-15 \%$ ' (Halleux and Strée, 2012), and in BedZed (Beddington Zero Energy Development, an environment friendly housing development in Hackbridge, London, England) the extra-cost in 2000 was 30\% (Energie Cities, 2008).

Note 5. Concerto is a program of the European Commission, initiated in 2003. It assists the development of renewable energy management throughout Europe, by supporting local communities in developing and implementing actions that are both sustainable and energy efficient.

Note 6. Translated from French: «Les prix des logements et leur localisation sont-ils adaptés aux capacités financières des profils des ménages?»

Note 7. Jean-Louis Borloo, 1st Sustainable City Conference, November 4th, 2009.

Note 8. Ministry of Ecology, Sustainable Development, Transports and, Housing (MoESDTH) -Ministère de 
l'Ecologie, du Développement Durable, des Transports et du Logement, 2008, Eco-Quartier -Application files for the Eco-quartier projects call, 2009, p.16.

Note 9. ARENE Ile de France, 2005, Sustainable neighborhoods, European examples, p. 9.

Note 10. In French: Bourgeois Bohemien, means: a liberal, highly educated person who combines a bourgeois, affluent lifestyle with nonconformist values and attitudes.

Note 11. Lille Metropolis, 2010, Eco-quartiers charter, p. 8.

Note 12. See. Art. R.323-1 and following of the Housing construction code (Code de construction de 1'habitat, $\mathrm{CCH}$ ), the arrêté of 30 December 1987 for the list of eligible improvements, newsletter No 88-01 of January 6 1988.

Note 13. Consecutive modifications of article R323-7 of the $\mathrm{CCH}$, see. www.legifrance.gouv.fr.

Note 14. The villages: Forcalquier, Hede-Bazouges, La Chapelle Sur Erdre, La Riviere, Sainte-Croix-aux-Mines, Longvic, Morez, Change. In the French overseas department of La Reunion: Saint Pierre.

Note 15 . Nanterre remains a middle-income municipality with a large share of low-income social housing but is in gentrification process due to its proximity to Paris and the western suburbs.

Note 16 . We used the term 'city' for any size of municipality since more precise labels are not employed in France.

Note 17. Category1: Census blocks with a high median income and high share of housing $\geqslant 100 \mathrm{~m}^{2}$, self-employed, craftsmen, managers and people with high educational degrees; Category 2: Census blocks with a high share of managers and academics; Category 3: Census blocks with a high share of non-graduates, blue collar workers, employees, subsidized housing, single parent families, unemployed, people with basic or intermediate qualifications, non-owners, and foreigners.

Note 18. The French Revolution abolished the historical French provinces (replacing them with an arbitrarily drawn system of departments (100), each responsible to the new French government, thus increasing centralization. Worried that power had become too centralized in Paris, the law of decentralization (1982) established a system of 22 regions with boundaries similar to those of the provinces of old, to promote local cultural differences and economic development. In 2016 the number of regions was reduced to 13.

Note 19. The solidarity tax on wealth is an annual direct wealth tax on residents with assets in excess of $€ 1,300,000$, (since 2011).

Note 20. Marne-la-Vallée is one of the five "new towns" established by General de Gaulle in the Paris region at the end of the 1960s to host new populations and improve living conditions. Public transportation and highways were provided to allow commuting to Paris. Today, Marne-la-Vallée hosts multinational corporations as well as research centers and a dense network of small and medium-sized businesses. It represents an important employment source.

Note 21. The unemployment rate for French youth is 28.3 percent, compared to 8.7 percent for the total population.

Note 22. Many poor neighborhoods, home to both socially disadvantaged populations and to foreigners, are characterized by a strong perception of insecurity (Pan Ké, 2012).

Note 23. The National Agency for Urban Renewal (ANRU) monitors the national urban renewal program (PNRU). Objective: To renovate 530 neighborhoods by 2013, totaling 40 billion euros of investment.

Note 24. Translated from French: «Les prix des logements et leur localisation sont-ils adaptés aux capacités financières des profils des ménages?».

Note 25. The Eco-quartier guidelines, 2016, Ministry of Housing, the Equality of territories and Rurality.

\section{Copyrights}

Copyright for this article is retained by the author(s), with first publication rights granted to the journal.

This is an open-access article distributed under the terms and conditions of the Creative Commons Attribution license (http://creativecommons.org/licenses/by/4.0/). 